\title{
A Tale of Two Pandemic Semesters: Examining the Longitudinal Impact of COVID-19 on Student Online Learning and Behaviors
}

\author{
Michael C. Budden, Connie B. Budden, and David C. Wyld
}

\section{ABSTRACT}

In the Spring of 2020, colleges and universities around the world joined primary and secondary education providers and businesses of all types in moving to an online, socially distant environment. Seen as necessary to stem the relentless spread of COVID-19, a deadly contagion, the move dramatically impacted lives, livelihoods, and social connections. In the Spring 2020 Semester, six weeks after the State of Louisiana issued a "stay at home" order, resulting in a move to $100 \%$ distance delivery of coursework, students at a public university in the state were surveyed for this research project as to the impact of the pandemic on their use of technology, social media, and online learning. Likewise, seven months later, at the end of the Fall 2020 Semester, students at the same university were again surveyed as to the impact of the move to using online technologies for everything from learning to shopping, communications, entertainment and more. Findings related to the use of technology and the impact of digital learning among respondents were investigated and compared between the groups to determine changes in online technology use for learning and more over time during this critical period during the coronavirus pandemic. The article concludes with a look ahead and an examination of areas for future research.

Published Online: July 22, 2021

ISSN: 2736-4534

DOI :10.24018/ejedu.2021.2.3.129

Michael C. Budden*

Southeastern Louisiana University,

Hammond, LA, USA

(e-mail: michael.budden@ selu.edu)

Connie B. Budden

Southeastern Louisiana University,

Hammond, LA, USA.

(e-mail: connie.budden@ selu.edu)

David C. Wyld

Southeastern Louisiana University,

Hammond, LA, USA.

(e-mail: david.wyld@ selu.edu)

*Corresponding Author

Keywords: COVID-19, communication, pandemic, online education, social media, technology.

\section{INTRODUCTION}

"It was the best of times, it was the worst of times, it was the age of wisdom, it was the age of foolishness, it was the epoch of belief, it was the epoch of incredulity, it was the season of light, it was the season of darkness, it was the spring of hope, it was the winter of despair."

--- Charles Dickens, "A Tale of Two Cities"

The phrase "the new normal" has taken on an ominous meaning since the beginning of 2020, when scenes of a spreading illness in Asia were shown on mainstream news sites across the globe. As the coronavirus made its way into Europe, across the ocean to North America and South America, Australia, and other countries down under, the threats to life, health and property became pronounced. The devastating impacts on health, lives and daily life led to a variety of efforts to stem the unrelenting spread of the virus [1]. And today, all of us - and our organizations and educational institutions - are seeking to find what exactly the new normal will be moving forward.

In early 2020, country after country began locking down their economies and restricting the movement and activities of businesses and people in an effort to slow the spread of what was soon declared a worldwide pandemic in the face of the COVID-19 outbreak. That declaration by the World
Health Organization in March proved to be a game changer [2]. Health care institutions and their employees suddenly found they were at "ground zero" in dealing with a new, dangerous pathogen that was relentless in its spread and harrowing impacts [3]. But it was not just health care providers who were impacted, as all businesses, even those deemed "essential" by government edicts, saw their operations severely impacted, with many being curtailed if not outright closed [4].

In mid-March 2020, Governor John Bel Edwards of Louisiana, in the wake of a report indicating that his state had one of the fastest growing rates of virus spread, joined eight other governors (and many world leaders) in issuing stay at home orders directly impacting organizations and individuals throughout his state [5]. Schools and universities were included in the "stay at home" order, and they were immediately impacted. The learning process was interrupted abruptly as schools - from kindergarten through high school. And yes, across higher education in Louisiana, all schools were suddenly shut down to physical learning, sending students who could return home, scurrying from campuses [6]. Students suddenly entered a tenuous environment that was changing quickly and deteriorating as jobs, on-campus housing, childcare for students who had children, and other support mechanisms - both for learning, for quality of life, and even for housing and nutrition, were either severely 
curtailed or ceased to exist [7].

The onset of the COVID-19 pandemic greatly changed not just retail shopping, but the retail landscape itself. There were panic-induced "runs" on retail stores as consumers sought to prepare for the pandemic. Supplies of consumer and health essentials including, bathroom tissue [8], disinfectants [9], and facemasks and other PPE (Personal Protective Equipment) [10], dish soaps and liquid hand soaps [11], and various meats, flour, and canned goods [12] quickly disappeared. Shopping shifted largely online, with significant surges in people buying across all categories of items [13], including groceries [14], as 2020 wore on and the pandemic worsened. The serious impact of the pandemic on the economy is underscored by the report that approximately 100,000 businesses - many of them small retailers and restaurants - had permanently shut down since March 2020 [15].

Like students, many - if not most - faculty members were also caught off-guard by the need to suddenly shift from what had been the norm of mostly in-person instruction to a "new normal" in the face of the threat of the coronavirus. Classes previously delivered in a traditional classroom setting had to transition to online delivery with little, if any, advance notice. The move, amid a climate of apprehension and worry, to a technology-dependent learning environment - an alien environment for many - created challenges. Some were prepared, others not so much.

The shift to online learning also exposed just how critical access to the Internet is for "life" today, prompting a real national debate over broadband policy [16]. Some $14 \%$ of US households with school-aged students at home do not have internet access and those households typically have household incomes of less than $\$ 50,000$ [17]. In fact, a recent Pew Research Center study indicated that $17 \%$ of adults access the internet exclusively through their smartphone and that percentage has roughly doubled since 2013, when only $8 \%$ of Americans reported no other home Internet access other than their mobile phone [18].

Obviously, the global movement of classes in primary, secondary and higher education to online delivery created challenges - which continue for many to this day. Those challenges and the impacts of the movement to online learning on college students are at the center of this study, as we seek to better understand students' adaptation to virtual learning in the context of their wider use of online technologies during the pandemic.

\section{Methodology}

Six weeks after the State of Louisiana's stay at home order was issued and the move to online learning was abruptly made, a questionnaire was submitted to students in the college of business at a public, regional university in the Southern United States. The survey was administered coinciding with the last week of the Spring 2020 Semester, and it inquired as to students' readiness for online learning and their online technology usage and behaviors during the previous six weeks. Then, during the last week of November (at the end of the Fall 2020 Semester) - approximately eight months after the implementation of the stay at home order the same questionnaire was administered to a sample of then current students in the same college of business. Both times, the questionnaires were administered to students in a convenience sampling of upper-level classes whose faculty agreed to participate. Most of the participants in the research were juniors and senior-level students, with a smaller group of graduate students also responding to the research survey. Both the questionnaire and research methodology were approved by the university's Institutional Review Board (IRB).

The overall objective of the study was to determine the preparation levels of students and their specific actions and attitudes as regards technology use during the pandemicinduced stay at home order in 2020. Specific variables/objectives investigated included a series of statements gauging the impact of the order on students' online behaviors, including their use of the Internet for shopping, communicating, finding entertainment, and yes, engaging in online learning. In the spring, 294 usable responses were submitted. At the end of fall survey, 339 usable responses were submitted. Not all respondents answered every question as allowed (and required under university IRB rules), so the total number responding to each question (n) varies slightly. The questionnaire was administered using Survey Monkey.

For each question investigated, a chi-square analysis using SPSS was conducted between the responses from students sampled in the Fall and Spring 2020 semesters. Statistically, one might expect since both groups of responses arise from the same general population of students (at the same college) that there will be no statistical difference between the measures as both are essentially estimates of the true population mean. At the same time, since the measures were taken more than six months apart, one might expect differences to appear. Findings of statistically significant differences between the groups were rare, but they did occur. They are discerned in the discussion in the next section.

\section{FINDINGS}

In this section, the authors will review the statements that the two groups of surveyed students responded to in the questionnaire, present the results of the survey and discuss the findings. These statements center around two general categories of online activities: (1) Those that connote the use of online technologies beyond remote learning (i.e. Use of Online News Sites, Shopping Online, Seeking Entertainment Online, and Use of Social Media); and (2) Those that represent the use of online technologies that are directly tied to student collaboration communication and remote learning (i.e. Use of Email; Use of FaceTime; Use of Online Meeting Sites [such as Zoom and Google Meet]; and Engaging in Online Learning. The coverage of the research results will follow this order in presenting and discussing the findings of the present study.

\section{A. Use of Online News Sites}

Media analytics has shown that the use of online news sites peaked in April 2020 during the early part of the pandemic and then eased in the latter part of the year [19]. Even though such usage peaked, online usage of news sites (digital visits) was more than $30 \%$ higher than pre-pandemic levels. Of course, traditional print media and broadcast media suffered 
during the same time period.

In the present research, to assess students' consumption of news from online sites, the survey participants were presented with the following statement:

Statement \#3: I have been reading news online more, the same or less since the order.

The student responses to this statement are summarized in Table I (Students Reading News Online, Spring 2020 vs. Fall 2020). Respondents in both surveys reported their usage of online news sites. A majority of both groups of respondents (53\%-55\%) reported using such sites more after the stay at home order than before. Similarly, only $8-9 \%$ reported using news sites less. Needless to say, with such close proportions, there was no significant difference between the two groups with regard to online news service use. Students are using such services more.

\begin{tabular}{ccccc} 
TABLE I: STUDENTS READING NEWS ONLINE, SPRING 2020 VS. FALL 2020 \\
\hline $\begin{array}{c}\text { Reading News } \\
\text { Online }\end{array}$ & More & $\begin{array}{c}\text { The } \\
\text { Same }\end{array}$ & Less & Sample Size \\
\hline Spring 2020 & 155 & 110 & 27 & $n=292$ \\
& $(53.1 \%)$ & $(37.7 \%)$ & $(9.2 \%)$ & \\
Fall 2020 & 186 & 125 & 27 & $n=338$ \\
\hline
\end{tabular}

Note: $\%=$ within semester.

\section{B. Shopping Online}

Online sales in the U.S. and across the globe increased markedly over the course of the pandemic to date [20]. In fact, online holiday sales alone during 2020 were up over $45 \%$ over holiday sales in 2019 [21]. This increase in sales may be responsible for some retailers delaying, reconsidering, or rescinding the previously announced closing of some stores as retail rebounds from the worst of the pandemic [22].

In the present research, to ascertain students' online shopping behaviors during the pandemic, the survey participants were presented with a series of statements in this regard. These were meant to capture the "intensity" of their online shopping activities. The first such statement dealt with just how much the students were buying online:

Statement \#5: I have generally been purchasing online more, the same amount or less since the order.

TABLE II: STUdENTS SHOPPING ONLINE, SPRING 2020 VS. FALL 2020

\begin{tabular}{ccccc}
\hline $\begin{array}{c}\text { Shopping } \\
\text { Online }\end{array}$ & More & $\begin{array}{c}\text { The } \\
\text { Same }\end{array}$ & Less & Sample Size \\
\hline \multirow{2}{*}{ Spring 2020 } & 160 & 98 & 32 & $n=290$ \\
& $(55.2 \%)$ & $(33.8 \%)$ & $(11.0 \%)$ & \\
Fall 2020 & 208 & 106 & 24 & $n=338$ \\
& $(61.5 \%)$ & $(31.4 \%)$ & $(7.1 \%)$ & \\
\hline
\end{tabular}

Note: $\%=$ within semester.

The student responses to this statement are summarized in Table II (Students Shopping Online, Spring 2020 vs. Fall 2020). Surely, college students contributed to the increase in online purchases nationally, and this was reflected in the results found in the present research. In the spring survey, more than $55 \%$ of respondents reported increases in online purchasing activities. That percentage increased to over $61 \%$ for fall semester respondents. Similarly, students reporting lower levels of online shopping in the fall, fell from the percentage reporting lower levels in the spring. The stay at home order resulted in respondents using the internet and technology more after the order than before. There was no statistically significant difference between the groups with regards to purchasing more online.

Online sales are increasing across the board for retailers with web presence in the wake of the pandemic. While brick and mortar stores sell more than online sites, the pace at which online is increasing is staggering and negatively impacting many stores who do not have an online presence or an effective online presence. U.S. online sales for 2020 totaled $\$ 1.8$ trillion, and globally, aggregate online retail in 2020 will breach the $\$ 4$ trillion dollar mark. And by 2023 , it is estimated that more than $90 \%$ of the U.S. population presently shopping online [23].

As another gauge of the intensity of students' online shopping behaviors during the pandemic, survey participants were asked to respond to the following statement:

Statement \#8: The number of online sites that I have made purchases from has decreased, stayed the same or increased.

TABLE III: NUMBER OF ONLINE SHOPPING SITES PURCHASED FROM,

\begin{tabular}{ccccc}
\multicolumn{5}{c}{ SPRING 2020 VS. FALL 2020 } \\
\hline $\begin{array}{c}\text { Number of Sites } \\
\text { Purchased From }\end{array}$ & Decreased & $\begin{array}{c}\text { The } \\
\text { Same }\end{array}$ & Increased & Sample Size \\
\hline Spring 2020 & $26(9.3 \%)$ & $\begin{array}{c}134 \\
(47.7 \%)\end{array}$ & $\begin{array}{c}121 \\
(43.1 \%)\end{array}$ & $n=281$ \\
Fall 2020 & $18(5.5 \%)$ & $\begin{array}{c}136 \\
(41.5 \%)\end{array}$ & $\begin{array}{c}174 \\
(53.0 \%)\end{array}$ & $n=328$ \\
\hline
\end{tabular}

Note: $\%=$ within semester.

The student responses to this statement are summarized in Table III (Number of Online Shopping Sites Purchased From, Spring 2020 vs. Fall 2020). Needless to say, the pandemic seems to be spurring the online purchase activities of respondents, and this question focused attention on the intensity of online shopping behavior by asking about the respondents' willingness to try, what for them, would be new retailers. As can be seen from the data, the findings revealed that students were more willing as the pandemic wore on to try "new" online merchants. Initially, approximately $43 \%$ reported increasing the number of websites purchased from, and over time, that number jumped to a majority $(53 \%)$ of students in the Fall 2020 Semester's results - a statistically significant increase at the .025 level. At the same time, in fall, a smaller percentage of students reported a decrease in the number of shopping sites compared to spring. Thus, the research results confirm that the pandemic caused individuals to be more open to not just buying online, but to buy from more and different online retailers as their needs and wants could best be satisfied by purchasing goods online.

The third online shopping "intensity" statement to which survey respondents were asked to respond was meant to capture if students were indeed buying a wider array of items from online merchants since the onset of the pandemic. It read as follows:

Statement \#10: The number of items I normally purchase online decreased, stayed the same or increased since the order.

The student responses to this statement are summarized in Table IV (Number of Items Purchased Online by Students, Spring 2020 vs. Fall 2020). 
TABLE IV: NuMBER OF ITEMS PURCHASED ONLINE BY STUDENTS, SPRING 2020 VS. FALL 2020

\begin{tabular}{ccccc}
\hline $\begin{array}{c}\text { Number of } \\
\text { Items Purchased } \\
\text { Online }\end{array}$ & Decreased & $\begin{array}{c}\text { The } \\
\text { Same }\end{array}$ & Increased & $\begin{array}{c}\text { Sample } \\
\text { Size }\end{array}$ \\
\hline Spring 2020 & $25(8.9 \%)$ & $\begin{array}{c}122 \\
(43.3 \%)\end{array}$ & $\begin{array}{c}135 \\
(47.9 \%)\end{array}$ & $n=282$ \\
Fall 2020 & $24(7.3 \%)$ & $\begin{array}{c}129 \\
(39.3 \%)\end{array}$ & $\begin{array}{c}175 \\
(53.4 \%)\end{array}$ & $n=328$ \\
\hline
\end{tabular}

Note: $\%=$ within semester.

Approximately $48 \%$ of spring respondents reported buying more items after the order than before. A slightly larger percentage of the fall respondents $(53.4 \%)$ reported increasing the number of items purchased after the stay at home order. With not too different levels of responses to the potential choices associated with the question, there was no statistical difference found between the groups.

The final online shopping "intensity" statement to which survey respondents were asked to respond was meant to ascertain if students were indeed spending more online than they were before March 2020. The statement read as follows:

Statement \#11: The amount I spend on online purchases has decreased, stayed the same or increased since the order.

The student responses to this statement are summarized in Table V (Total Online Spending by Students, Spring 2020 vs. Fall 2020).

TABLE V: TOTAL ONLINE SPENDING BY STUDENTS, SPRING 2020 VS. FALL 2020

\begin{tabular}{ccccc}
\multicolumn{5}{c}{ SPRING 2020 VS. FALL 2020 } \\
\hline $\begin{array}{c}\text { Total Online } \\
\text { Spending }\end{array}$ & Decreased & The Same & Increased & $\begin{array}{c}\text { Sample } \\
\text { Size }\end{array}$ \\
\hline Spring 2020 & 33 & 111 & 133 & $n=277$ \\
& $(11.9 \%)$ & $(40.1 \%)$ & $(48.0 \%)$ & \\
Fall 2020 & $28(8.5 \%)$ & $\begin{array}{c}106 \\
(31.4 \%)\end{array}$ & $\begin{array}{c}180 \\
(54.7 \%)\end{array}$ & $n=329$ \\
\hline
\end{tabular}

Note: $\%=$ within semester.

Online sales as a percentage of total retail sales have increased every year since 2007. In 2007, online sales accounted for only $5.1 \%$ of total retail sales, while in 2020 , online sales accounted for over $21 \%$ of retail sales, having jumped from under $16 \%$ in 2019 [24]. The pandemic impacted the growth of online retail sales, and this was reflected in the findings of the present research. Of the respondents in the spring survey, which was only six weeks into the stay at home order, $48 \%$ reported an increase in online purchasing. That percentage increased to over $54 \%$ seven months later as reported by fall respondents. At the same time, $8.5 \%$ of fall respondents reported a decrease in the amount spent on online purchases, down from almost $12 \%$ in spring.

The last statement to which students were asked to respond to regarding their online shopping behaviors during the course of the pandemic was in regard to going online to buy grocery items. The statement read as follows:

Statement \#4: I have been purchasing groceries using InstaCart, Shipt or similar delivery services more, the same amount or less since the order.

Grocery shopping was an activity that uniquely increased more than almost any other activity online during the COVID-19 pandemic, perhaps only exceeded by that of the other way of acquiring food while staying safe at home restaurant delivery [25]. In May 2020, at the height of the first wave of the COVID-19 pandemic, reported demand for Instacart's services for the previous few weeks was the highest in its history. In fact, Instacart realized an increase in customer order volume of 500\% year-over-year [26].

TABLE VI: STUDENTS BUYING GROCERIES ONLINE, SPRING 2020 VS. FALL 2020

\begin{tabular}{ccccc}
\hline $\begin{array}{c}\text { Suying Groceries } \\
\text { Online }\end{array}$ & Less & The Same & More & $\begin{array}{c}\text { Sample } \\
\text { Size }\end{array}$ \\
\hline Spring 2020 & 58 & 154 & 79 & $n=291$ \\
& $(19.9 \%)$ & $(52.9 \%)$ & $(27.1 \%)$ & \\
Fall 2020 & 66 & 181 & 89 & $n=336$ \\
& $(19.6 \%)$ & $(53.9 \%)$ & $(26.5 \%)$ & \\
\hline
\end{tabular}

Note: $\%=$ within semester.

As can be seen in Table VI (Students Buying Groceries Online, Spring 2020 vs. Fall 2020), students in the current study likewise reported an increased use of grocery delivery services overall. Approximately $27 \%$ of students in both surveys reported an increase in the use of grocery delivery services. This may be due to the fact members of the public were encouraged to stay home and to socially distance themselves from others. Somewhat unexpectedly however, approximately 1 in 5 respondents (19\%) in both surveys reported decreased use of such services. This may have been due to the reality of being "free" to actually go shopping in person, since attendance was not required on campus, as well as a felt need to get out and experience life, despite virus concerns. Also, students who may have been impacted negatively from an economic standpoint from the order's impact may have not been able to afford such grocery delivery services, and thus, shopped for themselves.

\section{Seeking Entertainment Online}

A third area under review in the present research was how the onset of the coronavirus pandemic spurred students to seek out more entertainment options for themselves online, rather than in-person. Specifically, this study examined two of the most popular online entertainment options, those being streaming music and video content.

In regard to seeking music online, the students surveyed for the present study were asked to respond to the following statement:

Statement \#9: The number of songs downloaded to my devices has decreased, stayed the same or increased since the stay at home order.

TABLE VII: STUDENTS DOWNLOADING MUSIC ONLINE, SPRING 2020 VS. FALL 2020

\begin{tabular}{ccccc}
\multicolumn{5}{c}{ SPRING 2020 VS. FALL 2020 } \\
\hline $\begin{array}{c}\text { Downloading } \\
\text { Music Online }\end{array}$ & Decreased & The Same & Increased & $\begin{array}{c}\text { Sample } \\
\text { Size }\end{array}$ \\
\hline Spring 2020 & $18(6.9 \%)$ & $153(59.1 \%)$ & $88(34.0 \%)$ & $\mathrm{n}=259$ \\
Fall 2020 & $16(5.2 \%)$ & $173(56.2 \%)$ & $\begin{array}{c}119 \\
(38.6 \%)\end{array}$ & $\mathrm{n}=308$ \\
\hline
\end{tabular}

Note: $\%=$ within semester.

Since 2004, the number of songs downloaded annually in the U.S. peaked at 1.392 billion songs in 2012, and that figure has subsequently declined every year since 2012. In fact, song downloads have now fallen to slightly more than 335 million songs annually [27]. As for the study respondents, Table VII (Students Downloading Music Online, Spring 2020 vs. Fall 2020) shows that the percentage of students downloading 
songs increased from $34 \%$ in the spring to $38.6 \%$ in the fall of 2020. It will be interesting to see if national sales of downloaded songs increased during the pandemic after seven years of decreased sales. However, the findings of the present research may also reflect the changing consumption patterns of music overall, with the pandemic further shifting consumers to the use of music streaming services over "buying" specific songs/albums for themselves [28].

In regards to seeking out video entertainment online, the students surveyed for the present study were asked to respond to the following statement:

Statement \#12: The number of movies I view on subscription services like Netflix has increased, decreased or stayed the same since the order.

Streaming video services are growing at an unprecedented pace today. In fact, Netflix, the leading player in the delivery of streaming video entertainment, surpassed 200 million subscribers in 2020 [29]. And while the trend toward streaming entertainment was well underway before the pandemic, COVID-19 - and the forced isolation that came with it - propelled the entire industry to meteoric growth, with year-over-year double-digit increases in 2020 in viewership, subscriptions, time spent on content, etc. for the major streaming services, including Netflix, Hulu, Disney+, Apple TV, NBC's Peacock and HBO Max [30].

As for the study respondents, Table VIII (Students Watching Content from Online Streaming Services, Spring 2020 vs. Fall 2020) below shows that yes, students were streaming markedly more movies and TV shows through such services after the onset of the pandemic than before. In spring, just over two-thirds of respondents reported increased levels of watching movies through online streaming. A slightly smaller percentage $(62.5 \%)$ of fall respondents reported watching more videos since the stay at home order. There was no significant difference in the two groups' use of video streaming services.

\begin{tabular}{|c|c|c|c|c|}
\hline \multicolumn{5}{|c|}{$\begin{array}{l}\text { TABLE VIII: STUDENTS WATCHING CONTENT FROM ONLINE } \\
\text { STREAMING SERVICES, SPRING } 2020 \text { VS. FALL } 2020\end{array}$} \\
\hline $\begin{array}{c}\text { Watching } \\
\text { Movies Via } \\
\text { Online } \\
\text { Streaming } \\
\text { Services }\end{array}$ & Decreased & The Same & Increased & $\begin{array}{c}\text { Sample } \\
\text { Size }\end{array}$ \\
\hline Spring 2020 & $7(2.5 \%)$ & $\begin{array}{c}87 \\
(30.7 \%)\end{array}$ & $\begin{array}{c}189 \\
(66.9 \%)\end{array}$ & $\mathrm{n}=283$ \\
\hline Fall 2020 & $13(4.0 \%)$ & $\begin{array}{c}110 \\
(33.5 \%)\end{array}$ & $\begin{array}{c}180 \\
(62.5 \%)\end{array}$ & $\mathrm{n}=328$ \\
\hline
\end{tabular}

Note: $\%=$ within semester.

\section{Use of Social Media}

Social media is undoubtedly very popular today globally and a major way that we communicate in the modern age. 1.82 billion people log into Facebook daily, spending an average of 58 minutes at the site. Further, the average American spends 38 minutes per day on Facebook, with $98 \%$ of users accessing the site through mobile devices. At the same time, Instagram has over 1.15 billion users and its largest user base is in the 18-24 years old age group [31]. And with the pandemic conditions meaning more time spent at home and isolated from family, friends, and coworkers, social media became a "a social lifeline" for many of us, helping the major social media platforms (Facebook, Twitter, and Instagram) reverse some of the trends of losing relevance and users - in 2020 and fueling the growth of newer platforms like TikTok [32].

TABLE IX: StUdents OVERALl USE OF Social Media,

\begin{tabular}{ccccc}
\multicolumn{5}{c}{ SPRING 2020 vS. FALL 2020 } \\
\hline $\begin{array}{c}\text { Overall Use of } \\
\text { Social Media }\end{array}$ & More & The Same & Less & $\begin{array}{c}\text { Sample } \\
\text { Size }\end{array}$ \\
\hline Spring 2020 & $\begin{array}{c}176 \\
(60.3 \%)\end{array}$ & $98(33.6 \%)$ & $\begin{array}{c}18 \\
(6.2 \%) \\
17\end{array}$ & $n=292$ \\
Fall 2020 & $\begin{array}{c}221 \\
65.2 \%)\end{array}$ & $\begin{array}{c}101 \\
(29.8 \%)\end{array}$ & $\begin{array}{c}15.0 \%) \\
n=339\end{array}$
\end{tabular}

Note: $\%=$ within semester.

Needless to say, respondents to the study are no strangers to social media sites. As can be seen in Table IX (Students Overall Social Media Usage, Spring 2020 vs. Fall 2020), when asked if they were using social media more or less (or the same amount) during the pandemic as they did prior to the COVID-19 outbreak, over $60 \%$ reported increasing their usage of social media during the pandemic and more than $65 \%$ of the fall group reported an increase in such usage. While the proportions don't indicate a significant difference, it does appear that fall respondents may be getting more inclined to seek social and entertaining avenues as the stay at home order continued to intrude on their regular activities.

TABLE X: StUdents Social MEdia Posting ACTIVITY, SPRING 2020 VS. FALL 2020

\begin{tabular}{ccccc}
\hline $\begin{array}{c}\text { Posting on } \\
\text { Social Media }\end{array}$ & More & The Same & Less & $\begin{array}{c}\text { Sample } \\
\text { Size }\end{array}$ \\
\hline Spring 2020 & 60 & 172 & 58 & $n=290$ \\
& $(20.7 \%)$ & $(59.3 \%)$ & $(20.0 \%)$ & \\
Fall 2020 & 86 & 183 & 70 & $n=339$ \\
\hline Note: $\%$ w within semester & $(25.4 \%)$ & $(54.0 \%)$ & $(20.6 \%)$ & \\
\end{tabular}

As can be seen in Table X (Students Social Media Posting Activity, Spring 2020 vs. Fall 2020), in the Spring 2020 survey, slightly more than $20 \%$ of respondents indicated they had increased the number of social media postings since the stay at home order. That percentage increased for fall respondents to a little more than $25 \%$. There was no statistically significant difference between the groups with regard to social media postings.

TABLE XI: STUDENTS JOINING NEW SOCIAL MEDIA PLATFORMS, SPRING 2020 VS. FALL 2020

\begin{tabular}{|c|c|c|c|c|}
\hline $\begin{array}{c}\text { Joined New } \\
\text { Social Media } \\
\text { Platforms }\end{array}$ & Disagree* & Neither & Agree** & $\begin{array}{c}\text { Sample } \\
\text { Size }\end{array}$ \\
\hline Spring 2020 & $\begin{array}{c}148 \\
(34.9 \%)\end{array}$ & $\begin{array}{c}65 \\
(24.2 \%)\end{array}$ & $\begin{array}{c}56 \\
(20.8 \%)\end{array}$ & $n=269$ \\
\hline Fall 2020 & $\begin{array}{c}143 \\
(44.3 \%)\end{array}$ & $\begin{array}{c}95 \\
(29.4 \%)\end{array}$ & $\begin{array}{c}85 \\
(26.3 \%)\end{array}$ & $n=323$ \\
\hline
\end{tabular}

Notes:

1. $\%=$ within semester.

2. Likert Statement - *Disagree=Strongly Disagree or Disagree; $* *$ Agree $=$ Strongly Agree or Agree** .

A related measure dealt with the joining of new social media platforms. As can be seen in Table XI (Students Joining New Social Media Platforms, Spring 2020 vs. Fall 2020), in the Spring 2020 survey, 20.8\% reported joining new social media platforms since the stay at home order. In the Fall 2020 survey administration, that percentage had risen to $26.3 \%$. A chi-square test indicated a significance level of 0.116 - beyond the minimum of 0.10 to be considered 
statistically different. However, the result indicates a broadening between the two groups. This could be explained by the intense interest in the U.S. Presidential Election, which was concurrent with the Fall 2020 Semester, and the attraction of some, especially those on the political extremes, to seek out alternative social media sites that were more in line with their political outlook [33].

In all, the findings in the present research are consistent with other studies which have found dramatically increased usage of - and changed usage patterns within - social media platforms across the board during the coronavirus pandemic [34]. And, as social media usage grows, students - and educators - have found new and innovative ways to make use of social media platforms for communication and a myriad of other uses not just for social reasons, but also for their educational pursuits [35]. While a thorough discussion of such is beyond the scope of the present study, this will certainly be an area of intense research interest over the next few years, especially in regard to how the pandemic and the shift to virtual learning has influenced such social media use, and vice versa as well.

\section{E. Use of Email}

The number of daily emails sent and received increased from a daily rate of 269 billion in 2017 to 306 billion per day by the end of 2020, and estimates are that number will continue to increase to over 361 billion daily emails by 2024 - just three years away [36]. And in the online learning environment, while certainly other communication and collaboration tools, such as Zoom and Google Meet, have come to the fore during the course of the pandemic, email communications are the fundamental way today for virtual learners to communicate with both their professors and each other [37]. Thus, email has taken on an even more important role in the present environment than ever before.

In regard to email usage since the onset of the COVID-19 pandemic, the students surveyed for the present study were asked to respond to the following statement:

Statement \#6: I have been sending emails more, the same or less since the order.

TABLE XII: STUDENTS USE OF EMAIL, SPRING 2020 VS. FALL 2020

\begin{tabular}{ccccc}
\hline Sending Emails & More & The Same & Less & $\begin{array}{c}\text { Sample } \\
\text { Size }\end{array}$ \\
\hline Spring 2020 & $200(68.7 \%)$ & $84(28.9 \%)$ & $7(2.4 \%)$ & $n=291$ \\
Fall 2020 & $217(64.0 \%)$ & $116(34.2 \%)$ & $6(1.8 \%)$ & $n=339$ \\
\hline
\end{tabular}

Note: $\%=$ within semester.

As can be seen in Table XII (Students Use of Email, Spring 2020 vs. Fall 2020), approximately two-thirds of both spring and fall respondents reported using emails more after the order than before. Interestingly, the percentage reporting an increase in fall actually declined to $64 \%$ from $68.7 \%$ in spring. The results of the two surveys for the research show that students were undoubtedly using email more after the issuance of the stay at home order in March 2020 than before. In fact, the number of students reporting using email less during the pandemic was only 7 respondents in spring and 6 respondents in fall. However, there was no statistically significant difference with regard to email usage found between the two survey periods, meaning that the shift was sudden and intransitory in terms of using email as a primary mode of communication during the pandemic.

\section{F. Use of FaceTime}

In 2019, prior to the pandemic, FaceTime was listed as one of the eleven apps college students would find most helpful for online education [38]. Indeed, FaceTime has proven to be highly useful for students from kindergarten to college to be able to communicate with their teachers and collaborate with one another in the wake of COVID-19-induced isolation and virtual learning [39].

In the present study, the students surveyed were asked to respond to the following statement regarding their use of FaceTime in the wake of the COVID-19 pandemic:

Statement \#1: I use FaceTime or similar apps on my phone more, less or the same amount since the stay at home order.

\begin{tabular}{ccccc}
\multicolumn{4}{c}{ TABLE XIII: STUDENTS USE OF FACETIME, SPRING 2020 VS. FALL 2020 } \\
\hline Use of FaceTime & More & The Same & Less & $\begin{array}{c}\text { Sample } \\
\text { Size }\end{array}$ \\
\hline Spring 2020 & $\begin{array}{c}169 \\
(58.3 \%)\end{array}$ & $\begin{array}{c}117 \\
(40.3 \%)\end{array}$ & $4(1.4 \%)$ & $n=290$ \\
Fall 2020 & $\begin{array}{c}205 \\
(60.7 \%)\end{array}$ & $\begin{array}{c}126 \\
(37.3 \%)\end{array}$ & $7(2.1 \%)$ & $n=338$ \\
\hline
\end{tabular}

Note: $\%=$ within semester.

As can be seen in Table XIII (Students Use of FaceTime, Spring 2020 vs. Fall 2020), approximately 60\% of both groups (spring and fall respondents) indicated they used FaceTime and similar apps on their phones more after the order than before. This parallels a report indicating mobile app usage was up $25 \%$ in the third quarter of 2020 [40]. It is interesting to note that only 11 respondents out of over 600 students surveyed in the current study indicated that they were using FaceTime or similar apps less after the order was issued. As might be expected from the approximately similar percentages between the groups, there was no statistical difference between the respondents of the two surveys.

\section{G. Use of Online Meeting Sites}

As might be expected, the use of Zoom, Google Meet and similar sites has soared during the pandemic. Day-over-day use of Google's Hangout/Google Meet was increasing by $60 \%$ in March 2020, and overall, the platform's utilization saw 25 times greater usage in March over its recorded use in January 2020 [39]. Zoom saw even more explosive growth being used for everything from online education to yoga classes to musical collaborations to family gatherings [41]. In fact, Zoom's user base zoomed from 10 million users in December 2019 to 300 million by April 2020 [42]!

In the present research, students were asked to respond to the following statement to gauge their use of Zoom, Google Meet, or other comparable online meeting sites:

Statement \#2: I am using Google Meet, Zoom and similar sites more, less or the same amount since the stay at home order.

TABLE XIV: STUDENTS USE OF ONLINE MEETING SiteS, SPRING 2020 VS. FALL 2020

\begin{tabular}{ccccc}
\multicolumn{5}{c}{ SPRING 2020 VS. FALL 2020 } \\
\hline $\begin{array}{c}\text { Use of Online } \\
\text { Meeting Sites }\end{array}$ & More & The Same & Less & $\begin{array}{c}\text { Sample } \\
\text { Size }\end{array}$ \\
\hline Spring 2020 & $269(92.4 \%)$ & $15(5.2 \%)$ & $7(2.4 \%)$ & $n=291$ \\
Fall 2020 & $313(92.3 \%)$ & $21(6.2 \%)$ & $5(1.5 \%)$ & $n=339$ \\
\hline
\end{tabular}

Note: $\%=$ within semester. 
The findings in regard to the students use of these online meeting platforms in the wake of the onset coronavirus pandemic is summarized in Table XIV (Students Use of Online Meeting Sites, Spring 2020 vs. Fall 2020). This study's respondents were among the many students not just nationally, but globally, who began using online meeting sites often due to the changes brought about by the pandemic. In fact, more than $92 \%$ of both spring and fall respondents reported using such meeting sites more, with again, only 12 students out of the over 600 surveyed reporting using online meeting sites less. Previous to the pandemic, the college had very few online courses, with face-to-face delivery being the norm. The move to online from face-to-face had a startling impact on the amount of online class meetings via digital technologies. As one can conjecture, the chi-square test revealed no significant differences between the responses from the spring and fall surveys, as both groups of respondents reported heavily-increased use of online meeting sites.

\section{H. Engaging in Online Learning}

The true focus of the entire research project was to ascertain students' engagement in online learning. The student respondents in the two survey groups were first asked to respond to the following statement:

\section{Statement \#14: Online courses have improved my communication skills.}

In this instance, students were asked to self-assess the impact that the move to $100 \%$ online courses had on their abilities to communicate effectively. A Likert scale, with responses ranging from strongly-disagree to strongly-agree, was used in this single instance in this survey to capture a more refined response from those surveyed. Table XV (Students' Beliefs That Online Learning Improved Their Communication Skills, Spring 2020 vs. Fall 2020) shows the findings in regard to this statement. Only $22 \%$ of respondents in spring and a similar $21 \%$ of respondents in fall, agreed or strongly agreed that online courses had improved their communication skills. At the same time, $47 \%$ in spring and $45 \%$ in fall disagreed or strongly disagreed that their communication skills had improved through the use of online courses. Approximately one-third of each semester's respondents did not agree nor disagree with the notion that their communication skills had improved since the order. The chi-square statistic of .918 indicates the close relationship of the responses between the spring and fall survey groups.

TABLE XV: STUDENTS' BELIEFS THAT ONLINE LEARNING IMPROVED

\begin{tabular}{cccc}
\multicolumn{4}{c}{ THEIR COMMUNICATION SKILLS, SPRING 2020 VS. FALL 2020 } \\
\hline $\begin{array}{c}\text { Communication } \\
\text { Skills }\end{array}$ & $\begin{array}{c}\text { Strongly } \\
\text { Disagree }\end{array}$ & Disagree & Agree \\
\hline Spring 2020 & $45(17 \%)$ & $81(30 \%)$ & $84(31 \%)$ \\
Fall 2020 & $59(18 \%)$ & $88(27 \%)$ & $106(33 \%)$ \\
Communication & Agree & Strongly & Sample \\
Skills & Agree & Size \\
Spring 2020 & $47(17 \%)$ & $13(5 \%)$ & $n=270$ \\
Fall 2020 & $56(17 \%)$ & $13(4 \%)$ & $n=322$ \\
\hline
\end{tabular}

Notes:

1. Rounding percentages may not equal $100 \%$.

2. ChiSq $=.918$.
A similar question asked students if they felt that online courses offered the ability to improve communication skills as well as in-class course offerings. In spring, $61 \%$ of respondents indicated they did not feel online course offerings offered the ability to improve communication skills as well as in-class offerings. In the fall, that percentage was approximately $57 \%$. The difference between the two groups was statistically insignificant.

Globally, dissatisfaction with the move to off-campus and a reliance on digital learning has been reported. Indeed, lawsuits against many institutions of higher learning have been filed, ostensibly citing dissatisfaction with content delivery modes and a failure of the defendant universities to provide what was promised [43].

At the same time, approximately $32 \%$ of spring respondents and $27 \%$ of fall respondents reported their ability to communicate had improved since the stay at home order. This may not be due only to the impact of online classwork, but increased usage of technology in other areas of their lives including the use of meetings sites, social media platforms and phone use.

\section{SUMmary AND CONCLUSIONS}

In March 2020, both students and faculty in Louisiana were caught off-guard when an order from the governor resulted in universities ordering students to leave campuses and rely on distance education to complete the Spring 2020 Semester. The order continued through summer semester and then fall. Students were surveyed at the end of spring and fall to assess the impact of the move to a new normal.

Students reported using social media, Facetime, digital meeting sites and phones more after the order than before. Both spring and fall students reported disappointment with the idea that distance learning had positively impacted their ability to communicate, though many reported their communication abilities had improved during the stay at home order. Only one measure - the number of online sites they had purchased from - saw a statistical difference between the two groups of respondents, with more fall students reporting the use of additional sites.

In future studies, the authors would like to continue sampling students at the same university/same college of business in order to further study how online technology use changes not only during the course of the pandemic, but now, in the recovery from the pandemic (hopefully) period we are entering as we go through the remainder of 2021 and over the next few years. The researchers would also like to further understand the correlations that exist between the propensity to use - or not use - online technologies (i.e. for shopping, for social purposes, for entertainment, etc.) and attitudes toward online learning. Such studies would seem especially worthwhile as entire institutions, colleges, and indeed, individual faculty grapple with how to move forward and balance online and "real" classroom offerings in the near future and over the immediate horizon. The authors would be open to collaborating with colleagues at other institutions outside of the Southern U.S. region where the study university is located and/or indeed abroad - to examine what differences and similarities can be found between regions in the United States and between American students and those 
in other countries. Finally, the researchers will be examining the trend data in regards to the online shopping data more in depth for future work in examining the changing world of marketing and retailing due to the coronavirus pandemic.

\section{REFERENCES}

[1] K. Sullivan. (February 19, 2021). A brief history of COVID, 1 year in Everyday Health. Available: https://www.everydayhealth.com/coronavirus/a-brief-history-ofcovid-one-year-in/.

[2] Mayo Clinic. (2020). Coronavirus disease 2019 (COVID-19). Available: https://www.mayoclinic.org/diseasesconditions/coronavirus/symptoms-causes/syc-20479963.

[3] B. Siwicki. (February 25, 2021). The $\mathrm{M} * \mathrm{~A} * \mathrm{~S} * \mathrm{H}$ model of care and pushing IT to the limit - lessons from a tough 12 months. Healthcare IT News. Available: https://www.healthcareitnews.com/news/mashmodel-care-and-pushing-it-limit-lessons-tough-12-months.

[4] L. Jones, D. Palumbo, and D. Brown (January 24, 2021). Coronavirus: How the pandemic has changed the world economy. BBC News. Available: https://www.bbc.com/news/business-51706225.

[5] M. Ballard and S. Karlin. (March 22, 2020). Louisiana issues statewide stay-at-home order to combat coronavirus spread. The Advocate. Available:

https://www.theadvocate.com/baton_rouge/news/coronavirus/article_ 922869e8-6c6d-11ea-aeee-6b6fd5e8f4bd.html.

[6] L.Guidry. (March 24, 2020). Coronavirus: After stay-at-home order Louisiana colleges ask students to leave campus. Lafayette Daily Advertiser.

Available:

https://www.theadvertiser.com/story/news/local/education/2020/03/24 /coronavirus-louisiana-universities-recommend-students-leavecampus/2901990001/.

[7] V. Yuen. (June 11, 2020). Center for American Progress Report: Mounting peril for public higher education during the coronavirus pandemic.

https://www.americanprogress.org/issues/educationpostsecondary/reports/2020/06/11/485963/mounting-peril-publichigher-education-coronavirus-pandemic/.

[8] A. Moore. (May 19, 2020). How the coronavirus created a toilet paper shortage. College of Natural Resources News - North Carolina State University. Available: https://cnr.ncsu.edu/news/2020/05/coronavirustoilet-paper-shortage/.

[9] K. Hessedel. (September 2, 2020). Your stories: Why can't I find Lysol or Clorox products. CBS8.com. Available: https://www.cbs8.com/article/news/investigations/your-stories8/your-stories-why-cant-i-find-lysol-or-clorox/509-f0a5da33-51424d4d-a291-9b198f0325a0.

[10] FDA (U.S. Food and Drug Administration). (June 19, 2020). FAQs on shortages of surgical masks and gowns during the COVID-19 Pandemic. Available: https://www.fda.gov/medical-devices/personalprotective-equipment-infection-control/faqs-shortages-surgicalmasks-and-gowns-during-covid-19-pandemic.

[11] H. Peterson. (October 22, 2020). Walmart stores post ominous signs warning of a 'national supply shortage' of dish soap that's expected to persist for weeks. Business Insider. Available: https://www.businessinsider.com/walmart-warns-a-national-supplyshortage-dish-soap-2019-10.

[12] M. Dominko. (November 20, 2020). 8 grocery items that may soon be in short supply again. Eatthis.com. Available: https://www.eatthis.com/grocery-items-out-of-stock-again-secondwave-hoarding/.

[13] C. Riley. (October 13, 2020). Online shopping has been turbocharged by the pandemic. There's no going back. CNN.com, Available: https://www.cnn.com/2020/10/11/investing/stocks-weekahead/index.html.

[14] K. Hurtig (March 2, 2021). Online grocery sales soar $133 \%$ year over year: Report. Winsight Grocery Business. Available: https://www.winsightgrocerybusiness.com/industry-partners/onlinegrocery-sales-soar-133-year-over-year-report.

[15] Yelp. (September 2020). Local economic impact report. Available: https://www.yelpeconomicaverage.com/business-closures-update-sep2020.

[16] M. Dano. (March 22, 2021). Debate heats up over the role of wireless in a universal broadband future. Broadband World News. Available: http://www.broadbandworldnews.com/document.asp?doc id $=768238$

[17] S. Noonoo. (March 20, 2020). Here's what schools can do for the millions of students without internet access. EdSurge.com. Available: https://www.edsurge.com/news/2020-03-20-here-s-what-schools-cando-for-the-millions-of-students-without-internet-access.

[18] M. Anderson. (June 13, 2019). Pew Research Center Report: Mobile Technology and Home Broadband 2019. Available: https://www.pewresearch.org/internet/2019/06/13/mobile-technologyand-home-broadband-2019/.

[19] B. Weitman and I. Essling. (August 19, 2020). Revisited: Media consumption during the Coronavirus pandemic. Comscore.com. Available: https://www.comscore.com/Insights/Blog/Revisited Media-Consumption-during-the-Coronavirus-Pandemic.

[20] F. Richter. (February 26, 2021). Pandemic accelerates shift to online retail. Statista. Available: https://www.statista.com/chart/14011/ecommerce-share-of-total-retail-sales/.

[21] Digitalcommerce360.com (February 16, 2021). Retailers hold onto stores in hopes of surge of shoppers. Available: https://www.digitalcommerce360.com/article/coronavirus-impactonline-retail/.

[22] K. Hardcastle. (May 31, 2021). How we're shopping now: 5 retai trends and the required rethink. Fortune. Available: https://www.forbes.com/sites/katehardcastle/2021/05/31/how-wereshopping-now-5-retail-trends-and-the-requiredrethink/?sh $=685 \mathrm{c} 2 \mathrm{~b} 806 \mathrm{ee} 4$.

[23] C. Ouellette. (January 6, 2021). Online shopping statistics you need to know in 2021. OptinMonster.com. Available: https://optinmonster.com/onlineshoppingstatistics/\#: : text=So\%20far\%2C\%2069\%25\%20of\%20Ame ricans,the $\% 20$ world $\% 20$ understand $\% 20$ the $\% 20$ benefits.

[24] F. Ali (January 29, 2021). "A decade in review: E-commerce sales vs. retail sales 2007-2020." Digitalcommerce360.com. Available: https://www.digitalcommerce360.com/article/e-commerce-salesretail-sales-ten-year-review/.

[25] L. Forman. (April 30, 2021). For food delivery, COVID-19 was a sugar high. The Wall Street Journal. Available: https://www.wsj.com/articles/for-food-delivery-covid-19-was-asugar-high-11619780401.

[26] M. Petrova. (May 13, 2020). Coronavirus is making grocery delivery services like Instacart really popular and they may be here to stay. CNBC. Available: https://www.cnbc.com/2020/05/13/coronavirusmaking-grocery-delivery-services-like-instacart-popular.html.

[27] Statista. (2021). Number of digital music single downloads in the US from 2004 to $2019 . \quad$ Available: https://www.statista.com/statistics/186688/downloads-of-digitalmusic-singles-in-the-us-since-2004/

[28] K. Westcott-Grant. (May 16, 2020). The future of music streaming: How COVID-19 has amplified emerging forms of music consumption. Forbes. Available: https://www.forbes.com/sites/kristinwestcottgrant/2020/05/16/thefuture-of-music-streaming-how-covid-19-has-amplified-emergingforms-of-music-consumption/?sh=22877c29444a

[29] J. E. Solsman. (January 20, 2021). Netflix subscriber growth soars past 200 million members. C/Net.com. Available: https://www.cnet.com/news/netflix-fourth-quarter-subscribers-soarpast-200-million-members-

stock/\#: :textit=In\%20the\%20US\%20and\%20Canada, 1.2\%20million $\% 20$ to\%2037.54\%20million.

[30] J. Thilmany. (March 18, 2021). Will the streaming video bubble burst post pandemic? The Forecast. Available: https://www.nutanix.com/theforecastbynutanix/technology/will-thestreaming-video-bubble-burst-post-pandemic.

[31] J. Bagadiya. (2021). 367 Social media statistics you must know is 2021. Social Media.com. Available: https://www.socialpilot.co/blog/socialmedia-statistics.

[32] R. Molla. (March 1, 2021). Posting less, posting more, and tired of it all: How the pandemic has changed social media. Recode. Available: https://www.vox.com/recode/22295131/social-media-use-pandemiccovid-19-instagram-tiktok.

[33] A. Hutchinson. (October 23, 2020). Can social media data predict the winner of the 2020 US presidential election? A look at the latest trends. Social Media Today. Available: https://www.socialmediatoday.com/news/can-social-media-datapredict-the-winner-of-the-2020-us-presidential-electi/587693/.

[34] J. Chen. (February 3, 2021). 36 essential social media marketing statistics to know for 2021. Sproutsocial.com. Available: https://sproutsocial.com/insights/social-media-statistics/.

[35] N. Selwyn. (October 25, 2020). How creative use of technology may have helped save schooling during the pandemic. The Conversation. Available: https://theconversation.com/how-creative-use-oftechnology-may-have-helped-save-schooling-during-the-pandemic146488 . 
[36] J. Johnson (February 2021). Number of sent and received emails per day worldwide from 2017 to 2024. Statista. Available: https://www.statista.com/statistics/456500/daily-number-of-e-mailsworldwide/.

[37] D. LoBianco. (June 5, 2020). Necessary changes as a result of mass virtual learning. Vault. Available: https://www.vault.com/blogs/admitone-vaults-mba-law-school-and-college-blog/necessary-changes-as-aresult-of-mass-virtual-learning.

[38] L. Tucker. (February 18, 2019). Most helpful apps for students. TopUniversities.com. Available: https://www.topuniversities.com/blog/most-helpful-apps-students.

[39] M. Burney. (March 25, 2020). How teachers are using technology to keep in touch with students during coronavirus school closures. Phys.org. Available: https://phys.org/news/2020-03-teacherstechnology-students-coronavirus-school.html.

[40] S. Condon. (March 31, 2020). Google's Hangout/Meet's daily usage soars during COVID-19 outbreak. ZDnet.com. Available: https://www.zdnet.com/article/google-hangouts-meets-daily-usagesoars-during-covid-19-outbreak/.

[41] D. C. Wyld. (April 25, 2020). Zooming ahead: The explosive growth of Zoom during the pandemic. The Startup. Available: https://medium.com/swlh/zooming-ahead-the-explosive-growth-ofzoom-during-the-pandemic-34f55b1f13e8.

[42] F. Richter. (June 3, 2021). Zoom keeps momentum as workers stay at home. Statista.

Available: https://www.statista.com/chart/21906/zoom-revenue/.

[43] K. Davis. (October 18, 2020). Student lawsuits asking for COVID-19 refunds pile up against universities. The San Diego Union-Tribune. Available:

https://www.sandiegouniontribune.com/news/courts/story/2020-1018/lawsuits-refunds-coronavirus-universities-san-diego.

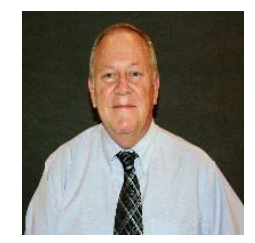

Dr. Michael C. Budden received a Ph.D. in Business Administration from the University of Arkansas (Fayetteville, Arkansas) with a major in marketing in 1982. His MBA was obtained from Southeastern Louisiana University (Hammond, Louisiana) and his BS in was earned at Louisiana State University (Baton Rouge, Louisiana).

$\mathrm{He}$ is the Benjamin Jones Professor of Retail Marketing at Southeastern Louisiana University. He served as a university administrator for 20 years, 14 of which were in the position of dean of business. Budden's books on trade secrets laws and merchant detention statutes (shoplifting laws) are published by Quorum Books. He has authored or co-authored over 200 articles and paper presentations.

Dr. Budden is a member of the Association for Business Communication. He teaches consumer behavior, marketing management and retail management courses.

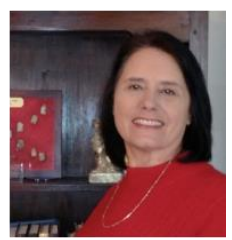

Connie B. Budden received her MBA from Auburn University Montgomery in 1992, where she also received her B.A. in Management. She has been teaching management at Southeastern Louisiana for 21 years where she is an instructor in management. Her primary teaching responsibilities involve international management, organizational behavior and study abroad courses to Costa Rica.

Ms. Budden has published over two dozen articles on a variety of management and educational topics. Her primary research interests involve student development, experiential and critical thinking exercises, and teaching pedagogy.

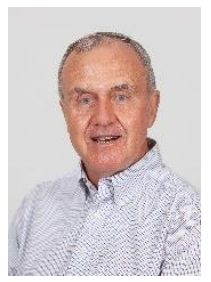

Dr. David C. Wyld received a D.B.A. in Management from the University of Memphis in 1993. Previously, he had earned both an M.B.A. and a B.B.A. from Stephen F. Austin State University in Nacogdoches, Texas in 1985 and 1984, respectively. He currently serves as the Merritt Professor of Strategic Management at Southeastern Louisiana University. Dr. Wyld is the founder and publisher of both Modern Business Press (publisher of leading edge journals) and The IDEA Publishers (publishing articles across a wide variety of topics giving both newbie authors and content marketers a platform for their ideas). As a prolific writer himself, he is a regular contributor to respected academic journals and widely-read trade and general interest publications. He has established himself as one of the leading academic experts on the applications of emerging technologies in both the public and private sectors. Dr. Wyld continues to serve as a strategic management consultant, a qualified expert witness, and an invited speaker to a wide variety of trade, corporate, governmental and academic audiences.

Dr. Wyld has been awarded Southeastern Louisiana University's President's Award for both Excellence in Teaching and Excellence in Research. As a recipient of both awards, he is among a select group of faculty to have been recognized in both roles. 